\title{
PENTINGNYA LABORATORIUM VIRTUAL BAHASA SEBAGAI PENUNJANG PROSES PEMBELAJARAN JARAK JAUH
}

\author{
Nunung Supratmi, Brillianing Pratiwi, Arini Noor Izzati \\ Universitas Terbuka (UT) Jakarta, Indonesia \\ Email: \\ nunung@ecampus.ut.ac.id; bpratiwi@ecampus.ut.ac.id; arini@ecampus.ut.ac.id \\ Received: 2021-02-15; Accepted: 2021-02-30; Published: 2021-03-10
}

\begin{abstract}
Abstrak
Seperti yang telah diketahui bersama bahwa proses pembelajaran jarak jauh tidak dibatasi oleh ruang dan waktu. Begitu juga untuk proses pembelajaran keterampilan berbahasa Indonesia yang dilaksanakan oleh Program Studi Pendidikan Bahasa dan Sastra Indonesia FKIP UT yang dilaksanakan secara jarak jauh. Untuk menunjang proses pembelajaran keterampilan berbahasa maka laboratorium virtual ini sangat penting untuk dikembangkan. Salah satu tujuannya adalah untuk memberikan pengalaman belajar di laboratorium bahasa walaupun dilaksanakan secara virtual. Artikel ini akan menjelaskan apa saja manfaat dari laboratorium virtual, perangkat apa saja yang sangat dibutuhkan dalam laboratorium virtual bahasa, dan kendala apa saja yang akan dihadapi untuk mengakses laboratorium virtual bahasa.
\end{abstract}

Kata Kunci: laboratorium; bahasa; virtual; jarak jauh

\begin{abstract}
As it is well known together that the process of distance learning is not limited by space and time. Similarly, the learning process of Indonesian language skills carried out by the Indonesian Language and Literature Education Study Program FKIP UT is carried out remotely. To support the learning process of language skills, this virtual laboratory is very important to be developed. One of the objectives is to provide a learning experience in the language laboratory even though it is implemented virtually. This article will explain what are the benefits of a virtual laboratory, what devices are needed in a language virtual laboratory, and what obstacles will be faced to access the language virtual laboratory.
\end{abstract}

Keywords: laboratory; language; virtual; remote

\section{PENDAHULUAN}

Sistem Pendidikan Tinggi Jarak Jauh (PTJJ) pada Universitas Terbuka (UT) saat ini mulai berkembang dengan baik. Hal tersebut terjadi karena tingkat fleksibilitas yang cukup tinggi. Melalui PTJJ mahasiswa dapat melakukan proses belajar sesuai dengan waktu dan tempat yang mereka tentukan sendiri. Oleh karena itu, sebagai lembaga PTJJ, kemampuan UT untuk menyediakan bahan ajar yang bervariasi serta memiliki kualitas yang tinggi merupakan hal yang sangat penting, terutama dalam usaha membantu mahasiswa dalam proses belajar secara mandiri. Selain itu, bahan ajar tersebut diharapkan dapat meningkatkan kemampuan mahasiswa secara efektif. Belajar secara mandiri merupakan hal utama ketika seseorang memutuskan menjadi mahasiswa UT. Bahan ajar yang disediakan UT didesain sesuai dengan karakteristik pembelajaran jarak jauh (PJJ) yaitu belajar mandiri.

Program Studi Pendidikan Bahasa sebagai salah satu program studi yang menyediakan sistem pembelajaran yang sesuai dengan karakteristiknya. Sebagaimana 
tujuan dari Program Studi Pendidikan Bahasa Indonesia di antaranya adalah (1) Menyediakan akses pendidikan tinggi yang berkualitas bagi pendidik bahasa Indonesia melalui penyelenggaraan berbagai program PTTJJ. (2) Menghasilkan pendidik bahasa Indonesia profesional yang mampu berkiprah secara global. (3) Memperluas akses partisipasi masyarakat dalam pendidikan berkelanjutan guna mewujudkan masyarakat berbasis pengetahuan (knowledgebased society). (4) Menghasilkan produk-produk akademik dalam bidang kependidikan dan keilmuan bahasa Indonesia, serta ke-PJJ-an. (5) Meningkatkan kualitas dan kuantitas penelitian dan pengembangan bidang kependidikan dan keilmuan bahasa dan sastra Indonesia, serta ke-PJJ-an. (6) Meningkatkan kemitraan dan jaringan kerja sama lintas budaya untuk memperkokoh persatuan dan kesatuan bangsa. (Katalog UT, 2019:168).

Berkaitan dengan hal menyediakan akses pendidikan yang mudah, tentunya belajar bahasa sesungguhnya merupakan interaksi komunikatif semua mahasswa dalam proses belajar mengajar termasuk di dalamnya berbagai variasi materi belajar yang dilatihkan. Adapun aspek-aspek yang membangun interaksi di antaranya adalah pemberian pertanyaan, pemberian penguatan, penguasaan bahan ajar dan peran pengajar.

Interaksi yang komunikatif ini merupakan kegiatan untuk mencapai kompetensi mahasiswa dalam suasana yang kooperatif, interpretatif, dan saling berbagi cara pengungkapannya. Forum yang para anggotanya dapat berpartisipasi dan berinteraksi dengan baik akan berfungsi sebagai forum komunikasi. Tentunya forum komunikasi yang di dalamnya terdapat aktivitas dari segala kemampuan mahasiswa dalam membangun pengetahuan dan keterampilan berbahasa. Hal tersebut tentunya menggunakan teknologi yang mendukung pembelajaran jarak jauh termasuk dalam pembelajaran bahasa. Seperti yang diungkapkan oleh Michael G. Moore dan G. Kearsley (2012:15), In distance education this communication takes place trough some kind of technology. Nowdays the most common technology is the computer with its browser linked into the internet, delivery text, audio, and video messages as well as providing a means interaction of instructors and learners, and of learners and learners.

Universitas Terbuka sebagai penyedia layanan pendidikan jarak jauh dan Program Studi Pendidikan Bahasa dan Sastra Indonesia khususnya sangat menyadari bahwa mahasiswa membutuhkan bentuk pembelajaran yang dapat diakses dimanapun, dan kapanpun. Apalagi di era keterbukaan pada saat sekarang ini dengan mahasiswa Program Studi Pendidikan Bahasa dan Sastra Indonesia sebagai individu mobilitas yang begitu tinggi membutuhkan sebuah perangkat laboraturium bahasa sebagai tempat yang sesuai untuk meningkatkan keterampilan berbahasanya.

Laboratorium bahasa merupakan alat untuk melatih pembelajar mendengarkan dan berbicara dalam bahasa yang sedang dipelajarinya dengan cara menyajikan materi pembelajaran yang telah disediakan sebelumnya. Seperti yang dikemukakan Danim (2008:22) bahwa Laboratorium bahasa adalah sebuah laboratorium yang dibuat untuk mempermudah penyampaian materi apapun di sebuah ruangan, pada umumnya digunakan untuk materi bahasa, baik bahasa Inggris, bahasa Indonesia, bahasa asing lainnya. Menurut Khitdhys (2010), laboratorium bahasa merujuk kepada seperangkat peralatan elektronik audio video yang terdiri atas instructor console sebagai mesin utama, dilengkapi dengan repeater language learning machine, tape recorder, DVD 
Player, video monitor, headset dan students booth (bilik siswa) yang dipasang dalam satu ruang kedap suara. Selain itu ada pula komponen komputer multimedia sebagai komponen tambahan yang dapat dikombinasikan dengan kesemuanya itu sehingga tampillah laboratorium bahasa multimedia.

Namun, bentuk perangkat laboraturium tersebut tentunya berbeda dengan perangkat laboraturium bahasa yang dibutuhkan pada institusi pendidikan jarak jauh. Bentuk perangkat laboraturium bahasa yang dikembangkan pada Program Studi Pendidikan Bahasa Indonesia FKIP UT berbentuk laboraturium virtual atau secara lebih tepatnya adalah laboraturium virtual bahasa. Laboratorium virtual ini adalah sebuah lingkungan interaktif untuk menciptakan sekaligus mengadakan eksperimen. Ini termasuk melakukan eksperimen dengan program simulasi yang bergantung pada bentuk teknologi virtual reality. Teknologi ini bisa diadaptasi untuk menciptakan laboratorium virtual untuk mensimulasi proses dan aksi seperti di laboratorium fisik (https://indonesiancloud.com). Jadi laboratorium virtual adalah cara terjangkau untuk institusi pendidikan atau universitas mendapatkan laboratorium untuk segala jenis subjek. Laboratorium virtual menawarkan pengguna khususnya guru, dosen, dan pelajar, mahasiswa sebuah pengalaman belajar yang mungkin hampir menyamai seperti di kelas fisik. Selain itu pengguna dapat mendesain, mengembangkan, dan mencapai eksperimen dengan melakukan bentuk praktik pengalaman maupun proses dalam konteks yang nyata. Seluruh pelajar atau mahasiswa dapat terlibat di seluruh prosesnya, tidak seperti di laboratorium fisik di mana hanya beberapa pelajar atau mahasiswa yang bisa melakukan proses serupa seperti instrukturnya.

\section{METODE}

Penelitian ini menggunakan metode penelitian dan pengembangan (Research and Development). Penelitian ini terbagi menjadi tiga tahap yaitu pertama, tahap analisis kebutuhan, kedua pengembangan laboratorium virtual bahasa hingga diperoleh prototipe, dan ketiga berupa ujicoba hasil penelitian. Penelitian ini merupakan penelitian tahuan pertama yaitu analisis kebutuhan terhadap laboratorium virtual bahasa.

Penelitian ini digunakan untuk menghasilkan produk berupa laboratorium bahasa dalam bentuk laboraturium virtual bahasa. Metode yang digunakan yaitu metode penelitian dan pengembangan (Research and Development). Penelitian (research) menurut Borg dan Gall merupakan suatu mekanisme atau kegiatan ilmiah dengan mengikuti aturan-aturan atau norma-norma penelitian yang sudah standar dan diakui secara universal. Sedangkan pengembangan (development) berarti suatu aktivitas yang merujuk pada penambahan, peningkatan, baik dari segi kuantitas maupun kualitas dari suatu kegiatan atau objek yang menjadi kegiatan. Langkah-langkah Penggunaan Metode Research and Development $(R \& D)$ :Potensi dan Masalah, Mengumpulkan Informasi, Desain produk, Validasi Desain, Perbaikan Desain, dan Ujicoba Produk. Adapun uraian model pengembangan Borg dan Gall, (http://adipwahyudi,blogspot.com/2011/model-penelitian-pengembangan-borg and.html), pengembangan dijelaskan sebagai berikut:

Educational research and development $(R \& D)$ is a process used to develop and validate educational products. The steps of this process are usually referred to as the $R$ $\& D$ cycle, which consists of studying research findings pertinent to the product to be 
developed, developing the product based on the finding, field testing it in the setting where it wil be used eventually, and revising it to correct the deficiencies found in the field testing stage. In indicate that product meets its behaviorally defined objectives.

Penelitian dan pengembangan pendidikan merupakan metode penelitian yang bertujuan meningkatkan mutu dan kualitas pendidikan melalui produk yang dihasilkan. Penelitian penelitian dan pengembangan bersifat longitudinal (beberapa tahap) dan pada penelitian ini terdisi dari tiga tahap (3 tahun). Tahun pertama penelitian dimulai potensi dan masalah $\rightarrow$ mengumpulkan informasi. Tahun kedua penelitian dimulai desain produk $\rightarrow$ validasi desain $\rightarrow$ perbaikan desain. Tahun ketiga ujicoba produk.

Responden dalam penelitian ini adalah mahasiswa dan dosen/tutor Prodi PBIN. Jumlah responden sebanyak 402 responden dengan rincian 235 mahasiswa yang mengikuti tutorial online 2020.2 dan 167 dosen/tutor Prodi PBIN. Jumlah responden yang mengisi angket sebanyak 131 responden dengan rincian 59 mahasiswa dan 72 dosen/tutor.

Penelitian ini menggunakan Instrumen yang berupa angket yang disebar menggunakan google form dan dikirim melalui email mahasiswa dan untuk dosen/tutor melalui whatsapp group dosen dan tutor prodi PBIN.

Teknik pengumpulan data dalam penelitian ini adalah menyebarkan angket. Selanjutnya, data yang terkumpul dianalisis dengan menggunakan teknik deskriptif kualitatif, penyajian data, dan kesimpulan.

Penelitian akan dilakukan melalui langkah-langkah yaitu membuat proposal, melakukan presentasi draft proposal dalam forum yang terdiri dari para pembimbing dan peserta lain untuk memperoleh masukan dan perbaikan proposal; Memfinalkan proposal berdasarkan masukan dari pembimbing dan peserta lain; Mengembangkan instrumen penelitian; Melakukan pengumpulan data melalui angket; Mengolah data dan menyajikan data; dan Melakukan penulisan laporan

Metode analisis data yang akan digunakan adalah metode kualitatif dengan menerapkan teknik analisis deskriptif. Teknik analisis deskriptif menganalisis data dengan cata mendeskripsikan atau menggambarkan data yang telah terkumpul tanpa bermaksud membuat kesimpulan yang berlaku untuk umum atau generalisasi. Analisis ini berupa akumulasi data dasar dalam bentuk deskripsi tidak mencari atau menerangkan saling hubungan, menguji hipotesis, atau melakukan penarikan kesimpulan.

\section{HASIL PENELITIAN DAN PEMBAHASAN}

Mengapa laboratorium virtual bahasa sangat penting bagi Program studi yang mengggunakn sistem pembelajaran jarak jauh. Sebelum menjawab pertanyaan tersebut, berdasarkan hasil penelitian di Program Studi Pendi PBIN FKIP UT yang menerapkan sistem pembelajaran jarak jauh, dari 131 mahasiswa yang mengisi angket diperoleh informasi hanya $23,7 \%$ yang pernah belajar keterampilan berbahasa di Laboratorium Bahasa secara fisik. Begitu juga dengan data penggunaan laboratorium virtual bahasa hanya $8,5 \%$. Data ini menunjukkan bahwa hanya sebagian kecil saja mahasiswa yang memiliki pengalaman belajar keterampilan berbahasa di laboratorium bahasa, baik secara fisik maupun virtual. Seharusnya, mahasiswa Pendidikan Bahasa dan Sastra Indonesia memiliki pengalaman belajar di laboratorium bahasa minimal laboratorium fisik sehingga pada saat sekolah tempat mereka mengajar memiliki 
laboratorium bahasa maka mereka dapat memanfaatkannya dengan baik karena pernah memiliki pengalaman belajar di laboratorium bahasa. Hal ini menunjukkan bahwa pentingnya laboratorium bahasa dimiliki oleh setiap Program Studi Pendidikan Bahasa dan sastra Indonesia.

Untuk mahasiswa Prodi PBIN FKIP UT yang tersebar di seluruh Indonesia, maka laboratorium yang diperlukan adalah laboratorium virtual bahasa. Mengapa harus laboratorium virtual bahasa? Berikut adalah manfaat dari laboratorium virtual yang dirangkum dari penelitan sebelumnya (2020: 14).

1) Mahasiswa dapat berlatih keterampilan berbahasa di manapun mahasiswa berada dan kapanpun mahasiswa memiliki waktu untuk belajar.

2) Dapat mendukung proses pembelajarana keterampilan berbahasa yaitu praktik kepekaan audio, visual, dan perekaman

3) Mendapatkan media pilihan belajar selain modul sehingga dapat menjadi sumber rujukan, memudahkan akses dalam pengembangan keilmuan serta membantu ketersampaian materi ajar

4) Di era digital, mahasiswa sudah akrab dengan kemajuan teknologi. Oleh karena itu, pembelajaran harus dikemas menarik proses sehingga pembelajaran lebih efektif dan maksimal.

5) Menambah kepercayaan diri mahasiswa karena menguasai kemahiran berbahasa dan memberikan pengalaman belajar yang lebih bermakna

6) Sebagai tempat untuk mengembangkan salah satu konten digital yang diperlukan untuk media pembelajaran konten digital

7) Mahasiswa dapat dilatih dan dapat berlatih melaksanakan pembelajaran bahasa Indonesia dengan berbagai model pembelajaran, pendekatan, metode dan teknik pembelajaran mulai dari anak usia prasekolah sampai orang dewasa .

8) Pandemi Covid-19 tidak memungkinkan belajar pada laboratorium nonvirtual dan PJJ menjadi kebutuhan dan menjadi salah satu bentuk bantuan belajar bahasa maka laboratorium bahasa sangat relevan membantu mahasiswa dalam belajar/berlatih dengan baik dan benar

9) Tiap tahun bertambah kosakata dan mahasiswa diharapkan mampu menambah kosakata dengan sosialisasi kosakata baru. Hal tersebut diperoleh dengan mengakses bahan bacaan secara mudah melalui laboratorium virtual bahasa.

Untuk mencapai manfaat terebut, maka pada laboratorium visual bahasa harus menyediakan perangkat untuk mendukung proses pembelajaran keterampilan berbahasa. Perangkat apa saja yang dibutuhkan oleh mahasiswa di dalam laboratorium bahasa adalah sebagai berikut.

1. Perangkat audio. Perangkat audio ini berfungsi untuk berlatih keterampilan menyimak mahasiswa.

2. Perangkat audio visual. Perangkat ini berfungsi untuk berlatih keterampilan menyimak dan berbicara

3. Alat merekam. Perangkat ini berfungsi untuk berlatih keterampilan berbicara dan membaca

4. Bahan latihan berbahasa. Perangkat ini berfungsi untuk berlatih keterampilan berbahasa mahasiswa (menyimak, berbicara, membaca, dan menulis) 
Selain perangkat pembelajaran tersebut, laboratorium virtual bahasa yang akan dikembangkan rencananya dapat mengakomodasi kegiatan berlatih berbahasa, baik secara individu, berpasangan, dan juga kelompok.

Seperti yang telah dijelaskan bahwa laboratorium virtual sangatlah baik digunakan sebagai salah satu media dalam proses pembelajaran keterampilan berbahasa. Akan tetapi, perlu juga diingat bahwa laboratorium juga memiliki kelamahan bagi penggunanya. Kelemahan inilah yang nantinya menjadi kendala besar mahasiswa untuk memanfaatkan laboratorium virtual bahasa. Kendala yang kemungkinan besar dihadapai adalah sebagai berikut.

1) Jaringan internet. Lemahnya jaringan internet merupakan kendala terbesar. Tanpa adanya jaringan internet maka laboratorium virtual tidak akan bisa diakses oleh mahasiswa

2) Kemampuan teknologinya. Kemampuan teknologi juga merupakan salah satu pendukung terjadinya kendala dalam mengakses laboratorium virtual. Akan tetapi kendala ini bisa diatasi dengan diberikannya petunjuk dalam mengakses laboratorium virtual bahasa.

3) Gangguan listrik. Gangguan listrik juga merupakan salah satu kendala yang dihadapi. Tetapi kendala ini tidak sebesar kendala yang lain.

4) Motivasi belajar mahasiswa. Tanpa adanya motivasi mahsiswa untuk belajar keterampilan berbahasa di laboratorium virtual maka proses pembelajaran di laboratorium tidak akan berjalan dengan baik

5) Kuota. Kemampuan membeli kuota internet juga salah satu yang mendukung terlaksana dan tidaknya mahasiswa belajar keterampilan berbahasa melalui laboratorium virtual.

\section{KESIMPULAN}

Terlepas dari kendala yang mungkin dihadapi oleh mahasiswa maupun dosen untuk mengakses laboratorium bahasa, tidak dapat dipungkiri bahwa laboratorium bahasa sangatlah besar manfaatnya bagi proses pembelajaran bahasa dan keberhasilan pembelajaran bahasa. Khususnya jenis laboraturium virtual bahasa yang memang dibutuhkan keberadaannya bagi proses pembelajaran jarak jauh. Terutama sebagai sarana virtual yang mendukung keberhasilan pembelajaran keterampilan berbahasa bagi mahasiswa Program studi Pendidikan Bahasa dan Sastra Indonesia Universitas Terbuka.

\section{REFERENSI}

Danim, Sudarwan, . 2008. Media Komunikasi Pendidikan. Jakarta : Bumi Aksara.

Farreira. 2010. Manfaat Laboratorium Virtual Online. Jakarta : Widyadara

Katalog UT 2019. Kurikulum Program Non-Pendas. Jakarta: Universitas Terbuka.

Moore, Michael G., 2012. Distance Education A Systems View of Online Learning. Third Edition. USA : Wadsworth 20 Davis Drive Belmont, CA 94002-3098. 
http://adipwahyudi,blogspot.com/2011/model-penelitian-pengembangan-borg and.html, diakses tanggal 18 Oktober 2021

https://indonesiancloud.com/pembelajaran-menggunakan-laboratorium-virtual/, diakses 16 Oktober 2021

Khitdhys. 2010. Laboratorium Bahasa Multimedia.

http://khitdhys.blogspot.co.id/2010/01/laboratorium-bahasa-multimedia-dan.html, diakses tanggal 18 Oktober 2021

Reismeiyanto. 2008. Pembelajaran Multimedia. Jakarta : Widyadara

Supratmi, Nunung, dkk. 2020. Laporan Penelitian pengembangan Laboratorium Virtual Bahasa. Jakarta: Universitas Terbuka

(C) 2021 by the authors. Submitted for possible open access publication under the terms and conditions of the Creative Commons Attribution (CC $\quad$ BY $\quad S A)$ license (https://creativecommons.org/licenses/by-sa/4.0/). 